\title{
Review Buku:
}

\author{
The Sociology Economy, A Systematic Inquiry \\ (Karya Alejandro Portes) $^{1}$ \\ Oleh \\ Derajad S Widhyharto ${ }^{2}$
}

\begin{abstract}
Abstrak
Membaca bukunya Alejandro Portes akan diingatkan kembali pada berbagai perdebatan teoritik sosiologi ekonomi lama dan baru yang mengusung kontribusi besar terhadap ide-ide jaringan sosial, teori organisasi, atau kebudayaan sosiologi. Dua konsep teori utamanya adalah "embeddedness" dan "konstruksi sosial dari institusi ekonomi". Di sisi lain, pembaca juga akan dipertemukan dengan berbagai investigasi sistematik dari praktik-praktik terkini di berbagai negara.
\end{abstract}

Kata kunci: jaringan sosial, embeddedness, konstruksi sosial institusi ekonomi.

\begin{abstract}
Alejandro Portes's book reminds us to various theoretical debates in the old and new sociology of economics, particularly which concerns on developing the ideas of social networks, theory of organization, and cultural sociology. His major theoretical concepts explain the concept of 'embeddedness' and 'the social contruct of economic institution'. The book also provides various systematic investigations in such themes based on contemporary practices found in various countries.
\end{abstract}

Keywords: social networks, embeddedness, social construct of economic institution.

\section{A. Pendahuluan}

Buku Portes memiliki sepuluh chapter, chapter awal berisi tentang dua pernyataan Portes tentang manifesto dan diskusi tentang meta-asumsi, bahwa tindakan ekonomi berorientasi secara sosial, tindakan rasional konsekuensinya tidak bisa diantisipasi, dan tentang kekuasaan. Kemudian Portes juga menyatakan kelahiran kembali sosiologi

\footnotetext{
1 Portes, Alejandro. 2010. The Sociology of Economy, A Systematic Inquiry. Princeton: Princeton University Press: ISBN: 978-0-691-14223-4 : ix + 307 pages

${ }^{2}$ Derajad S. Widhyharto: Pengajar di Jurusan Sosiologi Fisipol Universitas Gadjah Mada. Mendalami kajian Sosiologi Ekonomi.
} 
Jurnal Pemikiran Sosiologi Volume 1 No. 2, 2012

Review Buku: The Sociology Economy, A Systematic Inquiry (Karya Alejandro Portes)

Derajad S Widhyharto

ekonomi. Kelahiran tersebut telah dicatat dan dirayakan di sejumlah publikasi dan mencapai puncaknya dengan munculnya dua edisi beruntun dari buku besar, yang diedit oleh Neil J. Smelser dan Richard Swedberg. Hal tersebut merupakan prestasi sekaligus menambahkan pengaruh yang telah dicapai oleh artikel Granovetter tentang "embeddedness" dalam tindakan sosial ekonomi, hal ini merupakan sinyal bahwa argumentasi sosiologi ekonomi mulai dapat diterima dengan baik.

Empat chapter berikutnya berisi tentang mekanisme bekerjanya; modal sosial, kelas sosial, dan institusi sosial. Chapter selanjutnya,mengilustrasikan investigasi dan pemilihan strategi di lokasi riset, misalnya dengan penekanannya pada mengidentifikasi masalah aktual dengan cara mereformulasi dan mendefinisikan kembali meta-asumsi tersebut kedalam bentuk pengukuran, investigasi yang diwujudkan dalam pernyataan hipotetik.

\section{B. Telaah Isi Buku}

Portes mengawali penjelasan teoritiknya dengan meringkasnya menjadi tiga kategori, dalam metaprinsip teoritis, mekanisme ini jelas berfungsi untuk melakukan investigasi yang sistematis. Pertama komponen kognitif "lensa" dengan menentukan fokus-pendekatan mana yang dianggap tepat untuk melihat realitas. Lensa ini tidak lebih kuat atau lebih

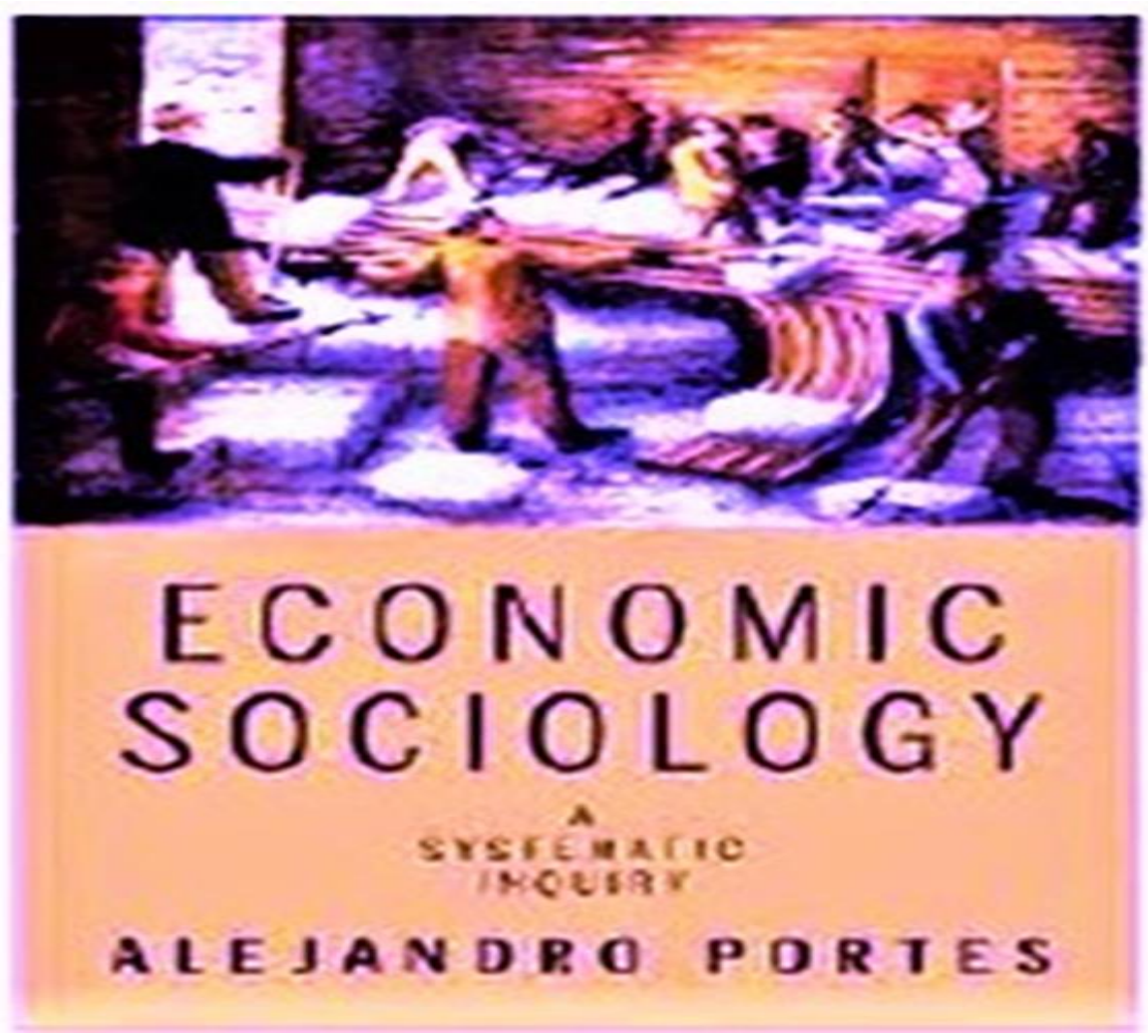

menggambarkan ekonomi informal, kantong etnis dan kelompok menengah, serta komunitas transnasional. Chapter akhir Portes kembali membicarakan analisis meta-asumsinya, lemah, konsep lensa tersebut digunakan secara berbeda dalam melakukan "zooming" di lokasi tertentu dari realitas empiris sebagai cara layak menyelidiki dan langsung fokus pada tema/topik. 
Jurnal Pemikiran Sosiologi Volume 1 No. 2, 2012

Review Buku: The Sociology Economy, A Systematic Inquiry (Karya Alejandro Portes)

Derajad S Widhyharto

Kategori kedua mencakup ide-ide yang dapat direalisasikan, dalam rangka memahami, mengklarifikasi, dan bahkan memprediksi peristiwa konkret. Hal tersebut dianggap mewakili instrumentasi yang dipatuhi oleh perspektif disiplin ilmu tertentu yang digunakan untuk menjelaskan fungsinya. Sedangkan, kategori ketiga terdiri dari lokasi yang dipilih untuk penyelidikan ekspansif teoritis bidang tertentu. Lokasi ini tentu tidak dipilih secara acak, tetapi mencerminkan panduan orientasi, lensa melalui lapangan mana untuk melihat realitas tadi.

Tujuan buku ini adalah untuk mengejar baris argumen dengan terlebih dahulu mempertimbangkan prinsip-prinsip yang mendasari asumsi kunci atau panduan lapangan dan kemudian dirangkaikan pengujian konsep yang jelas pada tingkat menengah yang dapat diterapkan dalam berbagai situasi di lapangan. Lalu dipilih untuk melacak asumsi kunci kembali sebelumnya diterbitkan, alasan metodologis tersebut diharapkan tidak memberikan kesan sebagai kumpulan esai. Portes mencoba untuk mengatasi kesan tersebut dengan menunjukkan bagaimana setiap konsep berhubungan dengan bidang asumsi yang dipilih dan bagaimana, pada gilirannya, mereka dapat digunakan untuk menjelaskan dan memprediksi masalah di lokasi tertentu pula.

Portes kemudian berencana untuk menguji asumsi dasar sosiologi ekonomi "meta-asumsi", beberapa mekanisme kunci dari penjelasan, dan penglihatan lokasi penelitian strategis. Terdapat tiga asumsi umum - berorientasi aksi sosial ekonomi, konsekuensi tak terduga dari tindakan purposive dan kekuasaan. Jelas ada juga merupakan mekanisme yang dipilih: modal sosial, kelas sosial, dan lembaga sosial. Ini akan diikuti dengan analisis dari tiga lokasi penelitian: ekonomi informal, kantong-kantong etnis dan kelompok tengkulak, dan komunitas transnasional. Lokasi ini memiliki dua karakteristik. Pertama, terdapat perbedaan yang paling sering dibahas dalam literatur, seperti perusahaan dan pasar. Kedua, sebagai tipe ideal, terdapat kesadaran atas mekanisme pasar. Jelas mekanisme dipilih bukan tanpa masalah mereka dan ini dibahas dalam bab-bab dari buku Portes tersebut.

Isu modal sosial digunakan untuk memainkan peran yang sangat berbeda dari yang dimaksudkan oleh pendiri sosiologi, kelas sosial memiliki penurunan era dalam ekonomi politik Marxis sebagai perspektif yang komprehensif; Sebaliknya, lembaga sosial telah mengalami kenaikan mendadak dalam popularitas, namun definisi telah menjadi begitu samar dan beragam seperti mengancam nilai heuristik-nya. Akhirnya, mungkin tidak segera jelas mengapa meta-ketiga dikutip - sehingga dengan asumsi, yaitu, mengapa mereka ditahan untuk menjadi dasar lengkap dari bidang mereka atau mengapa mereka ditempatkan pada tingkat yang berbeda abstraksi dari yang lain disebutkan? Untuk sementara, semua yang diminta pembaca dengan persetujuan awal terdapat 2 poin: (a) tidak semua yang meliputi teori umum itu diperlukan untuk mengembangkan sosiologi ekonomi ke depannya; (b) untuk melakukannya, namun, perbedaan yang diperlukan diantara konsep yang berbeda yang dapat mengisi suatu ruang, dengan fungsinya masing-masing dan tingkat relativitas keabstraksiannya.

Sejak ditemukannya teori-teori oleh Weber, Joseph Schumpeter, Thorstein Veblen dan lainnya, sosiologi ekonomi telah memberikan suatu hasil yang besar 
Jurnal Pemikiran Sosiologi Volume 1 No. 2, 2012

Review Buku: The Sociology Economy, A Systematic Inquiry (Karya Alejandro Portes)

Derajad S Widhyharto

kepada penemunya dan juga sebagai koreksi atas tradisi marginal ortodoks. Bagaimanapun janji itu hampir cukup terpenuhi sebagai kontekstual dalam bidang masa lalu, sekarang dan yang akan datang, untuk gagasan pendiri, dan sebagai peningkatan jumlah pembelajaran empiris memanggil mereka sebagai mantra, tetapi tanpa diakumulasikan kepada kemajuan yang teoritis. Untuk melangkah kedepan, kita harus memiliki bukti empiris yang menyatu di sekitar rangkaian konsep yang berlainan membuat mereka mengeluarkan nilai-nilai yang heuristik. Konsep (tipe ideal) adalah apa yang kita tahu dan mudah diingat sebagai pengalaman di berbagai penelitian.

\section{Pembahasan Kritis: Asumsi dan Praktik di}

\section{Lapangan}

Pertama, fungsi ekonomi informal di Republik Soviet Georgia Yahudi difokuskan pada produksi ilegal dan distribusi barang konsumen. Produksi terjadi di pabrik-pabrik yang dimiliki dan dengan bahan baku dipasok oleh negara. hukuman penjara menunggu mereka yang tertangkap. Meskipun dibayangi ancaman hukuman penjara, sistem berkembang dan berfungsi lancar selama bertahun-tahun. Butuh target keamanan dalam produksi rendah dan alokasi resmi limbah untuk menampung produksi yang lebih tinggi ilegal. Akuntansi selalu diubah. Lini produksi, misalnya, dinyatakan "dalam layanan" pada saat puncak produksi tidak resmi. input dan standar yang lebih rendah digunakan untuk melengkapi kuota resmi untuk meningkatkan penyediaan suku cadang, barang memasuki illegal.

Kedua, di desa-desa adat di sekitar kota Otavalo di Andes Ekuador, pemilik toko pakaian laki-laki dan kerajinan dari kulit lebih banyak penganut Protestan (penginjil, seperti yang disebut lokal) daripada Katolik. Alasannya adalah bahwa etika Protestan mendorong mereka untuk pencapaian yang lebih besar dari enterpreneurial, atau mereka menemukan doktrin evangelikal untuk menjadi lebih kompatibel dengan keyakinan mereka sendiri. Dengan memindahkan kesetiaan agama, para pengusaha ini menghapus sejumlah kewajiban sosial bagi laki-laki kepala keluarga yang terkait dengan Gereja Katolik dan organisasi lokal.

Ketiga, Italia yang terkenal sentra industri di wilayah pusat Emilia-Romagna kecil, mempunyai perusahaan yang sangat dinamis, banyak yang memulai sebagai perusahaan informal dan terus menggunakan input yang diproduksi oleh pekerja informal. Vittorio Capecchi, yang mempelajari sistem, hubungan keterlibatan dari eksploitasi murni atau persaingan mencirikan tindakan harian antara pengusaha dan pekerja dan di antara pemilik perusahaan. Perusahaan kecil dalam industri tekstil, keramik, metalurgi, dan lain-lain merespon dengan cepat permintaan pasar, yang mengkhususkan diri di pasar tertentu, bekerja sama dengan satu sama lain dalam merespon lonjakan permintaan, dan melawan manipulasi untuk memotong harga.

Keempat, Chile telah dipuji dalam beberapa tahun terakhir sebagai negara dengan ekonomi paling sukses di Amerika Latin dan sebagai contoh dari apa yang disebut "pembebasan pasar" dan mencapai sebutan negara dunia ketiga. Kondisi tersebut banyak mendapat pujian dan keberhasilan karena sebuah proses trial-and-error yang melihat ekonom muda yang terinspirasi oleh doktrin-doktrin neoliberal dari Chicago Milton Friedman, seorang profesor yang memperkenalkan reformasi radikal 
Jurnal Pemikiran Sosiologi Volume 1 No. 2, 2012

Review Buku: The Sociology Economy, A Systematic Inquiry (Karya Alejandro Portes)

Derajad S Widhyharto

untuk pasar terbuka dan merangsang investasi asing untuk menghindari kegagalan memproduksi stagnasi ekonomi serta pengangguran besarbesaran. Hanya karena "kebebasan" kebijakan yang diperkenalkan di bawah dictatorship Pinochet tetap dipertahankan oleh rezim militer.

Dinamika lapangan di berbagai negara tersebut memperkaya kajian sosiologi ekonomi "baru" yang berkembang pesat dalam beberapa tahun terakhir, kemunculan analisis kelas, etnis, informal ekonomi, dan komunitas transnasional telah memberikan nuansa eksotisme dan unik di tengah-tengah sistem ekonomi kapitalistik. Contoh-contoh yang berbeda tampaknya hanya mengilustrasikan keragaman, serta cara pandang dari titik yang berbeda pula mengenai trend dalam peristiwa ekonomi. Sudut pandang terhadap contoh masing-masing telah mendorong caranya sendiri dalam membentuk lima orientasi sosiologi ekonomi:

1. Kemunculan tindakan skeptis terhadap peristiwa ekonomi termasuk kegiatan ekonomi riil yang menilai "pertukaran" diasumsikan secara hukum dan pasar negara.

2. Tindakan skeptis terhadap peristiwa ekonomi merujuk pada kepentingan diri yang tak terkendali bersifat tunggal, atau motivasi utamanya semata-mata tindakan ekonomi.

3. Terdapat pengakuan umum bahwa transaksi ekonomi tidak terjadi dalam "ruang vakum" atau hampa udara melainkan dimasukkan ke dalam sistem budaya dan jaringan interaksi masyarakat.

4. Upaya mengapresiasi kenyataan dengan menyatakan rasionalitas diarahkan menuju tujuan eksplisit sering berakhir menghasilkan konsekuensi yang berbeda atau berlawanan dengan tujuan awalnya.

5. Terjadi penolakan keseluruhan dari peristiwa ekonomi pada tingkat lapangan dan penekanannya pada peran kekuasaan.
Dua poin pertama (No.1 dan 2) membedakan orientasi analitik titik keberangkatan sosiologi ekonomi dari ekonomi yang tepat, terutama dalam argumen neo-classical. Sedangkan tiga poin terakhir (No.3, 4 dan 5) mendefinisikan meta-asumsi kunci dari studi sosiologi ekonomi yang merujuk pada embeddedness sosial-ekonomi, konsekuensinya tak terduga dan memungkinkan terjadi selisih antara tujuan dan tindakan tersebut, kondisi tersebut berpengaruh terhadap kekuasaan.

Dalam sisa penjelasannya, Portes menganggap asumsi tersebut sebagai upaya "mereka" (contoh di atas), menetapkan kerangka kerja bagi munculnya mekanisme penjelasan lebih spesifik dan identifikasi argumentasi sosiologi ekonomi yang relevan untuk riset-riset lebih lanjut. Pilihan meta-asumsi berbeda dari yang konvensional disajikan dalam teks pada sosiologi ekonomi "baru" yang hanya mengidentifikasi dua poin pertama sebagai titik pijakan. Meskipun embeddedness inipun juga penting dikaji, hal itu tidak serta merta mengabaikan semua yang ada dalam orientasi teoritik sosiologi ekonomi. Sebagaimana terlihat dalam tiga orientasi terakhir. "Mereka" bukan hipotesis yang akan diuji, namun "lensa" di mana realitas dipahami dan dieksplorasi.

Hasil akhir dari proses di atas adalah telah muncul bentuk baru dari kapitalisme yang diatur untuk menghasilkan kemiripan dengan ekonomi maju Eropa Barat yang lebih dekat dibandingkan dengan praktek spontan golongan elit Amerika Latin pada masa lalu. Untuk tujuan akademis, pelajaran metodologis yang dapat diambil dari pengalaman ini adalah "de-embedding" dan "re-embedding" pasar dan pelaku pasar Polanyi dapat diperiksa, diukur, dan dimasukkan ke dalam proporsi yang jelas 
Jurnal Pemikiran Sosiologi Volume 1 No. 2, 2012

Review Buku: The Sociology Economy, A Systematic Inquiry (Karya Alejandro Portes)

Derajad S Widhyharto

dimana versi sosiologi ekonomi Granovetter belum menyebutkan dengan jelas. Sebagai konsep middle range, embeddedness relevan dengan banyak situasi karena dianggap dapat mendorong ketegangan abadi antara negara dan pasar dalam masyarakat yang makin kapitalistik.

\section{Kesimpulan}

Lalu bagaimana dengan sosiologi ekonomi di Indonesia yang menghadapi beragam karakter masyarakat mulai tradisional, sampai dengan postmodern? Merespon keragaman tersebut embededness muncul dalam berbagai argumentasi, dan perbedaan tingkat. Pada masyarakat tradisional embededness muncul dalam wujud pengorbanan terhadap budaya dan kebudayaan, masyarakat rela berkorban untuk tradisi atau "ritual sosial". Sementara, pada masyarakat post-modern muncul argumen stratifikasi, simbol dan peran sosial. Kritik muncul ketika embededness di Indonesia lebih dimaknai untuk mengeneralisasi ragam variasi dan kondisi riil masyarakat, sehingga sifat embededness-nya dinilai tidak cukup kritis melihat perbedaan. Asumsi tersebut mendorong pengkonstruksian peristiwa ekonomi secara seragam. Pada level ini buku Portes dapat memberikan pencerahan. Sebaliknya, sosiologi ekonomi tidak banyak mengalami perkembangan di Indonesia karena para akademisi tidak menjadikan Indonesia sebagai laboratorium (tolak ukur empris) dan belum banyak melakukan pengujian metodemetodologi sosiologi ekonomi, hal tersebut disayangkan mengingat variasi kejadian dan peristiwa ekonomi yang muncul banyak.
Mendiskusikan praktik sosiologi ekonomi di Indonesia dalam pandangan barat akan menemui jalan buntu ketika negara bukan sebagai penengah (wasit), melainkan terlibat sebagai pemain dalam pasar. Sebagai contoh, praktik CSR (Corporate Social Responsibility) di Indonesia bisa dikatakan menghamba pada konsep "embededness" yang hanya berpijak pada asumsi kuat dan lemah, asumsi tersebut makin mempertegas keterkaitannya dengan kekuasaan. Indikasinya ketika negara terlibat mengumpulkan uang CSR, sehingga negara tidak berdaya menyelesaikan berbagai pertikaian kegiatan CSR karena negara menjadi bagian dari pertikaian tersebut. Alhasil, perusahaan mengeluarkan uangnya sendiri, menyewa konsultan sendiri dan mengeksekusi sendiri kegiatan CSR. Jelas kondisi ini akan mendorong subyektifitas kepentingan sepihak daripada obyektifitas kepentingan umum. Jadi pelaksanaan CSR sebenarnya bukan katub penyelamat, melainkan melahirkan arena baru dengan pemain baru dan tentunya masalah baru.

\section{Daftar Pustaka}

Hann Chris and Hart Keith (ed). 2009. Market and Society: The Great Tranformation Today. New York: Cambrige University Press.

Granovetter, Mark. 1985. "Economic Action and Social Structure: The Problem of Embededness." American Journal of Sociology, Volume 91, issue 3 (November 1985), 481-510.

Portes, Alejandro. 2010. The Sociology of Economy, A Systematic Inquiry. Princeton: Princeton University Press 